\title{
Effects of Angiotensin-converting Enzyme Inhibition on Altered Renal Hemodynamics Induced by Low Protein Diet in the Rat
}

\author{
Emma Fernández-Repollet, Edilia Tapia, and Manuel Martínez-Maldonado \\ Departments of Pharmacology and Physiology, University of Puerto Rico, School of Medicine and Department of Medicine, Veterans \\ Administration Center, San Juan, Puerto Rico 00936
}

\begin{abstract}
We assessed the role of angiotensin II in mediating the alterations in renal hemodynamics known to result from low protein feeding to normal rats by examining the effect of the angiotensin-converting enzyme (ACE) inhibitor captopril. 2 wk of low protein (6\% casein) diet resulted in decreased glomerular filtration rate (normal protein [NP], 1.82 $\pm 0.17 \mathrm{vs.} \mathrm{low} \mathrm{protein}$ [LP], 0.76 $\pm 0.01 \mathrm{ml} / \mathrm{min} ; \boldsymbol{P}<0.05$ ) and renal plasma flow (NP, $6.7 \pm 0.2$ vs. $\mathrm{LP}, 3.3 \pm 0.3 \mathrm{ml} / \mathrm{min} ; P<0.05)$; renal vascular resistance rose $\left(\mathrm{NP}, 8.7 \pm 0.4 \mathrm{vs}\right.$. $\mathrm{LP}, 19.8 \pm 1.4 \mathrm{dyn} \cdot \mathrm{s}$ per $\mathrm{cm}^{5}$; $P<0.05)$. These changes were accompanied by a significant decrease in plasma renin activity (NP, $7.0 \pm 0.7$ vs. $L P, 4.4 \pm 0.8$ ng A I/ml per h; $P<0.05)$, plasma aldosterone concentration (NP, 7.0 \pm 0.6 vs. LP, $4.1 \pm 0.7 \mathrm{ng} / \mathrm{dl} ; P<0.05$ ), and urinary $\mathrm{PGE}_{2}$ excretion (NP, 3,120 \pm 511 vs. LP, $648 \pm 95 \mathrm{pg} / \mathrm{mgCr}, P$ $<0.05$ ); by contrast renal renin content was significantly increased (NP, 2,587 \pm 273 vs. LP, 7,032 \pm 654 ng A I/mg protein; $P<0.05)$. Treatment with captopril $(30 \mathrm{mg} / \mathrm{kg}$ per d) raised glomerular filtration rate (GFR; LP + capt, 1.6 0 0.2 $\mathrm{ml} / \mathrm{min}$ ) and renal plasma flow (RPF; LP + capt, 6.7 \pm 0.7 $\mathrm{ml} / \mathrm{min}$ ), and reduced renal vascular resistance ( $L P+$ capt, $9.2 \pm 0.5 \mathrm{dyn} / \mathrm{s}$ per $\mathrm{cm}^{5}$ ) in low protein-fed animals. These values were not different from those measured in untreated and captopril-treated rats fed a normal (23\%) protein diet. There were no changes in systemic mean arterial pressure in any group of rats. These data provide evidence that intrarenal angiotensin II mediates the changes in intrarenal hemodynamics induced by protein deprivation. The effects of low protein feeding may be partly potentiated by the reduction in $\mathrm{PGE}_{2}$ synthesis. However, the normalization of GFR and RPF in view of only modest increases in $\mathrm{PGE}_{2}$ excretion after captopril (LP, 648 \pm 95 vs. LP + capt; 1,131 $\pm 82 \mathrm{pg} / \mathrm{mgCr} ; P$ $<0.05$ ) suggests that if $\mathrm{PGE}_{2}$ is involved in these changes, it plays a permissive but not essential role in the increased renovascular resistance.
\end{abstract}

\section{Introduction}

Protein-calorie malnutrition in the human results in proportional reductions in glomerular filtration rate and renal plasma flow so that filtration fraction remains relatively constant (1).

Part of this work was presented at the Annual Meeting of the American Society of Nephrology, Washington, DC, December 1986.

Address reprint requests to Manuel Martinez-Maldonado, M.D., Veterans Administration Center, G.P.O. Box 4867, San Juan, PR 00936.

Received for publication 12 August 1986 and in revised form 10 June 1987.

The Journal of Clinical Investigation, Inc.

Volume 80, October 1987, 1045-1049
The mechanism for these changes have been partially elucidated. Studies in Munich-Wistar rats fed a low protein diet for 6 mo have shown that single nephron glomerular filtration rate (SNGFR) ${ }^{1}$ is reduced in superficial nephrons in proportion to overall glomerular filtration rate (GFR). The fall in GFR appears to be the direct consequence of an increase in single nephron pre- and postglomerular resistances, which reduce plasma flow per nephron $\left(Q_{A}\right)$, and of a reduction in the glomerular ultrafiltration coefficient $\left(K_{f}\right)(2)$. These alterations in glomerular function are very similar to the effects induced by the exogenous administration of angiotensin II (A II) in normal rats $(3,4)$. Thus it is possible that the renal functional changes seen in protein-deprived humans and rats are mediated by changes in the secretion of or sensitivity to A II.

The present study was designed to evaluate the effects of short-term low protein feeding on overall renal hemodynamics and function, and the role of A II and prostaglandins in mediating the functional alterations evident during this early phase of protein deprivation.

\section{Methods}

Experimental animals and dietary regimen. 64 male Wistar-Furth rats (National Cancer Institute, Fort Detrick, MD) weighing $90 \pm 10 \mathrm{~g}$ were used in the studies. Rats were fed a normal protein diet (23\% casein, ICN Nutritional Biochemicals, Co., Plainview, NY) with normal sodium $(0.5 \%)$ and potassium $(1.3 \%)$ content and allowed free access to food and water for $1 \mathrm{wk}$. After this equilibration period, rats were divided into two subgroups and pair-fed isocaloric diets containing either low (6\% casein) or normal (23\% casein) protein for 2 wk. Rats maintained on normal protein (NP) diets were pair-fed according to the rats fed low protein diet (LP rats) by feeding them a quantity of the control diet equal to the amount eaten by the LP rats during the preceding $24 \mathrm{~h}$. Details on the composition of the experimental diets are shown in Table I.

Balance studies. 12 rats were placed in individual metabolism cages and subjected to the dietary regimens described above. A 4-d balance study was carried out during the second week of protein deprivation in both normal $(n=6)$ and low $(n=6)$ protein rats. Balance studies consisted of daily measurements of body weight, food, and water intake and urine volume, osmolality, sodium, potassium, and urea concentration. Urinary $\mathrm{PGE}_{2}$ excretion was measured in aliquots of 24-h urine samples collected on ice. At the end of the study, blood samples for the determination of plasma electrolyte, protein and aldosterone concentration, and plasma renin activity (PRA) were obtained by tail bleeding in the conscious animal. Basal renin activity obtained by

1. Abbreviations used in this paper: A II, angiotensin II; ABP, arterial blood pressure; ACE, angiotensin-converting enzyme; GFR, glomerular filtration rate; Hct, hematocrit; $K_{f}$, glomerular ultrafiltration coefficient; LP, low protein; NP, normal protein; $\mathrm{PAH}$, para-amino hippuric acid; $P \mathrm{PE}_{2}$, prostaglandin $\mathrm{E}_{2} ; \mathrm{PRA}$, plasma renin activity; $\mathrm{Q}_{\mathrm{A}}$, glomerular plasma flow; RPF, renal plasma flow; RVP, renal venous pressure; RVR, renal vascular resistance; SNGFR, single nephron glomerular filtration rate. 
decapitation gave values of $6.8 \pm 0.4(n=8)$, a value not different from those obtained by tail bleeding. Similar balance studies were performed in an additional 12 rats (6 NP, 6 LP) that were chronically treated with the converting enzyme inhibitor captopril (SQ 14225, was a gift from Squibb \& Sons, Inc., Princeton, NJ). The inhibitor was administered by gavage at 8:00 AM each day during the last $6 \mathrm{~d}$ of the study $(30 \mathrm{mg} / \mathrm{kg}$ body wt per d).

Clearance studies. Clearance studies were performed in awake control $(n=12)$ and captropril-treated $(n=12)$ rats fed either a low or a normal protein diet. Rats were lightly anesthetized with ether to insert polyethylene catheters (PE50) in a femoral vein for intravenous infusions and in the left carotid artery for measurements of arterial blood pressure and blood sampling. The bladder was also cannulated through a small suprapubic incision. During surgery, rats were infused with isotonic saline containing inulin $(6 \mathrm{mg} / \mathrm{ml})$ and $P A H(0.1 \mathrm{mg} / \mathrm{ml})$ at a rate of $0.03 \mathrm{ml} / \mathrm{min}$. ABP was monitored with an electronic transducer (Statham Instruments, Hato Rey, PR) connected to a direct writing recorder (model 775A, Hewlett-Packard Co., Palo Alto, CA). The rats were allowed to recover from ether anesthesia for $2 \mathrm{~h}$. After this equilibration period, a minimum of three clearance determinations were made in each animal. Blood samples were obtained at the midpoint of each 30-min period.

Glomerular filtration rate and renal plasma flow were determined from the clearance of inulin and PAH, respectively. The GFR/RPF ratio equates the filtration fraction. Renal vascular resistance (RVR) was calculated as: $\mathrm{RVR}=(\mathrm{ABP}-\mathrm{RVP}) /(\mathrm{RBF}) \times 7.962 \times 10^{4}$, where $\mathrm{ABP}=$ mean arterial blood pressure, $\mathrm{RVP}=$ renal venous pressure $(\mathrm{RVP}$ $=3 \mathrm{mmHg}), \mathrm{RBF}=\mathrm{RPF} /(1-\mathrm{Hct})$, and the factor $7.962 \times 10^{4}$ was used to convert resistance to dyn $\cdot \mathrm{s} \cdot \mathrm{cm}^{5}$. The value for $\mathrm{RVP}$ was based on measurements in $\mathrm{NP}(n=4)$ and $\operatorname{LP}(n=5)$ rats. The values were $3.1 \pm 0.3$ for the former and $2.9 \pm 0.4$ for the latter.

Kidney renin content. In a separate group of rats fed a normal ( $n$ $=8)$ and a low $(n=8)$ protein diet for $2 \mathrm{wk}$, plasma renin concentration and kidney renin content were determined from the amount of angiotensin I generated in the presence of excess substrate. Blood samples were obtained by tail bleeding in the conscious animal. Under pentobarbital anesthesia the left kidney of control and experimental rats was immediately excised, weighed, and kept at $-20^{\circ} \mathrm{C}$ in $1 \mathrm{ml}$ of distilled water until its renin content was measured. For renal renin extraction, the frozen tissue was thawed at room temperature and refrozen. This procedure was repeated three times (5). The tissue was homogenized in $0.2 \mathrm{M}$ phosphate buffer, $\mathrm{pH} 6.5$, containing $1.5 \%$ ammonium EDTA. The insoluble residue was separated by centrifugation and redissolved. The procedure was repeated twice and the supernatant was adjusted to obtain a final dilution of 1:100. Protein concentration and angiotensin I generated were measured in aliquots of the final solution. Values of kidney renin content are expressed as

\section{Table I. Dietary Composition of Normal and Low Protein Diets}

\begin{tabular}{lll} 
& Normal protein & Low protein \\
\hline & $\%$ & $\%$ \\
Casein & 23.0 & 6.0 \\
Sucrose & 27.5 & 35.0 \\
Dextrin & 34.3 & 43.8 \\
Fat & 7.0 & 7.0 \\
Vitamins & 2.0 & 2.0 \\
1-Cystine & 0.2 & 0.2 \\
Mineral mix & 4.0 & 4.0 \\
Sodium & 0.5 & 0.5 \\
Potassium & 1.3 & 1.3 \\
Calcium & 0.6 & 0.6 \\
Phosphorus & 0.3 & 0.3 \\
\hline
\end{tabular}

nanograms AI per milligram protein. Protein was measured by Lowry's method (6).

Analytical methods. Sodium and potassium concentrations in plasma and urine were measured by flame photometry (Beckman Instruments, Inc., Fullerton, CA). Plasma and urine urea concentration were measured colorimetrically using the methods of Natelson et al. (7). Total plasma protein concentration was measured by a modification of Lowry's method (6) using bovine serum albumin as standard.

PRA was measured by determination of the amount of angiotensin I generated during $1 \mathrm{~h}$ of incubation of $37^{\circ} \mathrm{C}$ with inhibitors of converting enzyme and angiotensinases. Angiotensin I concentration was measured by radioimmunoassay (New England Nuclear, Boston, MA). ${ }^{125}$ I-Angiotensin I was counted in a model 110 Picker refrigerated beta/gamma counter. Values are expressed as $\mathrm{ng} \mathrm{A} \mathrm{I/ml} \mathrm{per} h$.

Plasma aldosterone concentration was measured by direct radioimmunoassay (8) using materials purchased from Abbott Laboratories, North Chicago, IL. Values are expressed as nanograms per deciliter.

Urinary $\mathrm{PGE}_{2}$ was extracted and measured by radioimmunoassay as previously described (9) using materials purchased from New England Nuclear. Values were expressed as picograms per milligram of creatinine.

Statistical methods. The Prophet system was used for data storage, statistical analyses, and graphics. Statistical analyses were done using standard programs contained in Prophet. Groups were compared using Student's $t$ test, while comparison within groups was done by paired $t$ analysis. Nonparametric methods (Mann, Whitney, and Wilcoxon rank sum tests) were used when appropriate. In addition all data was submitted to analysis of variance. There were no differences in the statistical results by the two main analyses used. A $P$ value of $<0.05$ was considered significant.

\section{Results}

As shown in Table II, 2 wk of low protein intake resulted in a significant decrease in body weight, differences in urine flow rate, and water and food intake. No significant urine sodium and potassium excretion were observed.

2 wk after LP intake plasma sodium and potassium concentrations remained unchanged while plasma urea and protein concentration were significantly diminished (Table III).

PRA, plasma aldosterone concentration, and the urinary excretion of $\mathrm{PGE}_{2}$ were found to be significantly diminished in the low protein group at the end of the study (Table IV).

The results of clearance studies are shown in Table V. The rats used in these studies demonstrated a fall in body weight as

Table II. Balance Study Data

\begin{tabular}{|c|c|c|c|c|}
\hline & \multirow[b]{2}{*}{ NP } & \multirow[b]{2}{*}{ LP } & \multicolumn{2}{|l|}{ Captopril } \\
\hline & & & NP & LP \\
\hline Body weight (g) & $202 \pm 3$ & $138 \pm 6^{*}$ & $205 \pm 2$ & $135 \pm 4^{*}$ \\
\hline $\begin{array}{l}\text { Urine flow rate } \\
(m l / 24 h)\end{array}$ & $24 \pm 1$ & $14 \pm 1^{*}$ & $26 \pm 1$ & $14 \pm 1^{*}$ \\
\hline $\begin{array}{c}\mathrm{H}_{2} \mathrm{O} \text { intake } \\
(\mathrm{ml} / 24 \mathrm{~h})\end{array}$ & $29 \pm 1$ & $19 \pm 1^{*}$ & $34 \pm 2$ & $21 \pm 1^{*}$ \\
\hline $\begin{array}{l}\text { Food intake } \\
\qquad(g / 24 h)\end{array}$ & $10.7 \pm 0.4$ & $10.4 \pm 0.6$ & $8.6 \pm 0.4$ & $8.73 \pm 0.3$ \\
\hline $\mathrm{U}_{\mathrm{Na}} \mathrm{V}(\mu E q / 24 h)$ & $1,629 \pm 141$ & $1,550 \pm 69$ & $1,987 \pm 64$ & $1,729 \pm 81$ \\
\hline $\mathrm{U}_{\mathrm{K}} \mathrm{V}(\mu E q / 24 h)$ & $1,265 \pm 46$ & $1,210 \pm 62$ & $1,042 \pm 67$ & $945 \pm 27$ \\
\hline
\end{tabular}

$\mathrm{U}_{\mathrm{Na}} \mathrm{V}$, urinary sodium excretion. $\mathrm{U}_{\mathrm{K}} \mathrm{V}$, urinary potassium excretion. $n=6$ in each group.

* Significantly different from NP rats in the same group; $P<0.05$. 
Table III. Changes in Plasma Sodium, Potassium, Urea, and Protein Concentration

\begin{tabular}{lllll}
\hline & & \multicolumn{3}{l}{ Captopril } \\
\cline { 4 - 5 } $\begin{array}{l}\text { Plasma } \\
\text { concentration }\end{array}$ & $\mathrm{NP}$ & $\mathrm{LP}$ & $\mathrm{NP}$ & $\mathrm{LP}$ \\
\hline $\begin{array}{l}\text { Sodium } \\
\quad(m E q / \text { liter })\end{array}$ & $145 \pm 1$ & $146 \pm 1$ & $143 \pm 1$ & $144 \pm 1$ \\
$\begin{array}{l}\text { Potassium } \\
(m E q / \text { liter })\end{array}$ & $3.8 \pm 0.1$ & $4.0 \pm 0.1$ & $3.8 \pm 0.2$ & $4.1 \pm 0.2$ \\
Urea $(m g / d l)$ & $14.8 \pm 0.4$ & $3.9 \pm 0.4^{*}$ & $16.7 \pm 1.2$ & $3.4 \pm 0.3^{*}$ \\
Protein $(m g / d l)$ & $7.5 \pm 0.1$ & $6.6 \pm 0.2^{*}$ & $7.7 \pm 0.2$ & $6.1 \pm 0.2^{*}$ \\
& & & & \\
\hline
\end{tabular}

$n=6$ in each group.

* Significantly different from NP rats in the same group; $P<0.05$.

a result of low protein feeding. No significant difference in mean arterial pressure was detected between control and experimental rats. Protein deprivation, however, was associated with a significant decrease in GFR and RPF, and a significant increase in RVR. Filtration fraction remained unaltered after 2 wk of low protein intake.

To assess whether the effects of protein deprivation on renin concentration in the kidney parallel those effects observed in the systemic circulation, the concentration of renin in the kidney was measured in normal and low protein-fed rats. As shown in Table VI, kidney renin concentration was significantly higher in the protein-deficient group. The increase in renal renin content contrasts with the reduction in plasma renin observed in low protein-fed rats.

Treatment with the converting enzyme inhibitor captopril did not alter the effects of protein deprivation on body weight, urine flow rate, food and water intake, or urinary sodium and potassium excretion (Table II). Similarly, captopril treatment did not alter the effects of protein depletion on plasma electrolyte values (Table III). In addition, PRA and plasma aldosterone concentration remained significantly diminished in the low protein as compared with NP group despite the expected changes (increased PRA and low PA) in absolute values induced by the treatment with captopril (Table IV).

As shown in Table IV urine $\mathrm{PGE}_{2}$ excretion was reduced by LP as compared with NP. Treatment with captopril in NP resulted in a tendency to increase in $\mathrm{PGE}_{2}$ excretion, but this

Table IV. Changes in PRA, Plasma Aldosterone (PA) Concentration, and Urinary $P G E_{2}$ Excretion $\left(U P G E_{2} V\right.$ )

\begin{tabular}{|c|c|c|c|c|}
\hline & \multirow[b]{2}{*}{ NP } & \multirow[b]{2}{*}{$\mathbf{L P}$} & \multicolumn{2}{|l|}{ Captopril } \\
\hline & & & NP & LP \\
\hline PRA & $7.0 \pm 0.7$ & $4.4 \pm 0.8^{*}$ & $68 \pm 5^{\ddagger}$ & $47 \pm 4^{* \neq \S}$ \\
\hline PA & $7.0 \pm 0.6$ & $4.1 \pm 0.7^{*}$ & $5.9 \pm 0.3^{\ddagger}$ & $2.8 \pm 0.2^{* \neq \S}$ \\
\hline $\mathrm{UPGE}_{2} \mathrm{~V}$ & $3,120 \pm 511$ & $648 \pm 95^{*}$ & $4,977 \pm 998$ & $1,131 \pm 83^{* \S}$ \\
\hline
\end{tabular}

PRA, ng A I/ml per h; PA, ng/dl; UPGE 2 V, ng/mg creatinine. $n=6$ in each group.

* Significantly different from NP rats in the same group; $P<0.05$.

‡ Significantly different from their respective group not receiving captopril.

${ }^{\S} \mathrm{LP}+$ captopril vs. NP; $P<0.05$ (results by ANOVA were identical).
Table V. Clearance Studies Data

\begin{tabular}{lcccc}
\hline & & \multicolumn{3}{l}{ Captopril } \\
\cline { 3 - 5 } & $\mathrm{NP}$ & LP & $\mathrm{NP}$ & $\mathrm{LP}$ \\
\hline Body weight $(\mathrm{g})$ & $214 \pm 11$ & $140 \pm 21^{*}$ & $192 \pm 16$ & $164 \pm 3^{*}$ \\
Mean arterial & & & & \\
$\quad$ pressure $(\mathrm{mm} \mathrm{mg})$ & $123 \pm 6$ & $130 \pm 4$ & $119 \pm 5$ & $122 \pm 3$ \\
GFR $(\mathrm{ml} / \mathrm{min})$ & $1.82 \pm 0.17$ & $0.76 \pm 0.01^{*}$ & $1.68 \pm 0.01$ & $1.60 \pm 0.17^{*}$ \\
RPF $(\mathrm{ml} / \mathrm{min})$ & $6.7 \pm 0.2$ & $3.3 \pm 0.3^{*}$ & $6.9 \pm 0.6$ & $6.7 \pm 0.7^{*}$ \\
RVR $\left(\right.$ dyn $\left./ \mathrm{s} \mathrm{per} \mathrm{cm}^{5}\right)$ & $8.7 \pm 0.4$ & $19.8 \pm 1.4^{*}$ & $8.3 \pm 0.8$ & $9.2 \pm 0.5^{*}$ \\
Filtration fraction & $0.27 \pm 0.02$ & $0.24 \pm 0.01$ & $0.25 \pm 0.01$ & $0.24 \pm 0.01$ \\
& & & & \\
\hline
\end{tabular}

$n=6$ in each group. No significant differences were found by ANOVA between NP, LP, and LP + captopril groups for all variables. * Significantly different from NP rats; $P<0.05$. " Significantly different from LP without captopril; $P<0.05$.

did not achieve significance when compared with NP without captopril. By contrast, whereas $\mathrm{UPGE}_{2} \mathrm{~V}$ in $\mathrm{LP}+$ captopril was significantly lower than in either NP or NP + captopril, the value of $L P+$ captopril was significantly higher than the value of $L P$ alone.

In the low protein-fed animals treated with captopril (Table V) a significant decrease in body weight occurred that was no different from that of the low protein untreated group. No significant difference in mean arterial pressure was observed between normal and low protein-fed rats. On the other hand, GFR, RPF, and RVR were equal to the values in untreated NP and in captopril-treated NP rats and significantly different from those in the untreated LP group. No significant changes in filtration fraction were detected.

\section{Discussion}

Low protein diet resulted in decreased body weight and a fall in total plasma protein and urea concentration. As a result, total urine flow fell despite adequate fluid intake. There were no changes in plasma sodium or potassium concentrations nor in urine sodium and potassium excretion as a result of the diet.

The present studies demonstrate that low protein feeding of young rats produced a state of altered renal hemodynamics that can be prevented by chronic treatment with an angiotensin I-converting enzyme inhibitor. The likelihood that A II is partly responsible for the changes in intrarenal hemodynamics had been infered from the findings of Ichikawa et al. (2). These investigators fed a low (6\%) protein diet to weanling MunichWistar rats for 6 mo before performing clearance and micropuncture studies. At the end of this period of time, glomerular filtration rate was lower in rats fed a low protein diet as compared with an isocaloric normal protein-fed group and a group allowed normal protein chow ad lib. The change in overall

Table VI. Effect of Protein Deprivation on Renal Renin Content

\begin{tabular}{ll}
\hline & Kidney renin concentration \\
\hline & $n g A I / m g$ protein \\
NP $(n=8)$ & $2,587 \pm 273$ \\
LP $(n=8)$ & $7,032 \pm 654^{*}$
\end{tabular}

$* P<0.05$. 
GFR was associated with a proportional reduction in single nephron GFR. Measurements of the determinants of SNGFR revealed that glomerular plasma flow was reduced as a consequence of elevated afferent and efferent arteriolar resistances. Furthermore, there was a dramatic reduction in the ultrafiltration coefficient $\left(K_{\mathrm{f}}\right)$. The similarity of these findings and those obtained when A II is given intravenously to rats $(3,4)$ did not escape the attention of the investigators (2).

The present studies reveal that in the rat, as in man (10), even short-term ( $2 \mathrm{wk}$ ) low protein feeding can induce changes in glomerular filtration rate without changes in mean arterial pressure (Table V). These alterations in GFR were the result of a reduction in RPF, which in turn arose from an increase in renovascular resistance. The increased resistance resulted, at least in part, from the dramatic reduction in the synthesis of renal prostaglandins induced by low protein feeding. Reduction in PGE production may have also increased the vasoconstrictor response to intrarenal release of A II. Clearly, as shown in Table IV, renin release into the circulation was diminished by low protein feeding. Nevertheless, this was probably not the result of decreased synthesis of renin because renal renin content was markedly elevated in low protein rats as compared with controls. Moreover (vide infra), captopril raised plasma renin 10-fold in LP rats, indicating that alteration in synthesis of renin alone does not explain the low plasma levels. While the possibility remains that renal renin release is impaired by low protein feeding the elevated intrarenal renin could have led to increased local production of A II and its consequences.

Pretreatment of rats with the angiotensin I-converting enzyme inhibitor captopril did not change the overall effect of low protein feeding. Body weight and the plasma concentration of protein and urea were lower in the low protein than in the normal protein-fed rats. Urine flow was lower, but sodium and potassium excretion were identical in both groups. Mean arterial pressure did not differ between the two groups, but overall GFR and RPF were still lower and renovascular resistance higher in low than in normal protein-fed rats.

More important was the fact that comparison of normal protein-untreated, normal protein captopril-treated, and low protein captopril-treated rats demonstrated values for GFR, RPF, and renovascular resistance that were identical in all groups. It can be concluded that captopril prevented the intrarenal effects of low protein feeding. The most likely explanation for these findings is that, as already discussed, increased intrarenal angiotensin production played a critical role in the hemodynamic changes observed.

That captopril was indeed effective can be deduced from Table IV. Captopril caused a 10-fold increase in PRA in both normal and low protein rats, the usual consequence of its inhibitory effect on the converting enzyme. Furthermore, it reduced plasma aldosterone concentration in both groups of rats treated with captopril as compared with the untreated groups. This effect undoubtedly resulted from the fall in circulating A II induced by captopril. In addition, captopril partly restored the production of prostaglandins in low protein-fed rats (the LP + captopril values were significantly different from LP values). This effect could have partly contributed to the reversal of increased renovascular resistance and to restore renal plasma flow to normal.

The possibility that the beneficial effects of captopril in restoring GFR also resulted from its protective effect on bradykinin destruction cannot be evaluated from our results. Al- though a role for bradykinin in restoring GFR remains a possibility, it seems unlikely to us because bradykinin reduces $K_{f}$ (11). In fact, treatment with angiotensin-converting enzyme inhibitors leads to increases in $K_{\mathrm{f}}$ both in diabetic rats and rats with reduced renal mass $(12,13)$.

By contrast, numerous studies have demonstrated that captopril and other ACE inhibitors can revert angiotensin IImediated hemodynamic changes. The alterations in the determinants of glomerular filtration induced by A II when the peptide is infused into animals or generated endogenously have been shown to be reversible or blocked by saralasin (14). For example, the renal hemodynamic changes seen in human congestive heart failure are not unlike those seen in the low protein-fed animals and can be reverted by captopril (15).

An important observation can be gleaned from our studies. Low protein diet drastically impairs the synthesis of $\mathrm{PGE}_{2}$ as assessed from its excretion by the kidney. The effect was not the result of a fall in urine flow because the $\mathrm{PGE}_{2}$ values fall by $>70 \%$ while urine flow changes $<25 \%$ (16). Moreover, the values were corrected for creatinine excretion to eliminate any contribution of changes in GFR to the reduced PGE excretion. This observation is in agreement with studies in which protein deficiency in rats also resulted in $\sim 50 \%$ reduction in the synthesis of cyclooxygenase-derived products by neutrophils and in the biosynthesis of $\mathrm{PGE}_{2}$ of rat kidney medulla (17). Clearly, a long-term study of the chronic effects of reduced PGE excretion on renal function during protein deprivation must be carried out to assess its exact consequences.

In summary, low protein feeding (6\%) to weanling rats results in marked alterations in renal hemodynamics after 2 wk. The changes are characterized by a rise in renal vascular resistance and decreases in GFR and RPF. Marked reduction in prostaglandin synthesis and the intrarenal effects of angiotensin seem to contribute to these changes. The changes are reversed by an angiotensin I-converting enzyme inhibitor. It appears that angiotensin II may be the common pathway effector of these changes.

\section{Acknowledgments}

The technical help of Ms. Lourdes Algarin and the secretarial help of Ms. Anna Carmen Rivera are gratefully appreciated. Edilia Tapia Rodríguez, D.D.S., was a Research Fellow during the performance of this study. Her current address is Renal Laboratory, Instituto Nacional de Cardiología, Mexico, D.F., Mexico.

This work was supported by National Institute of Health grants RO1-AM-30201 and PHS-RR-08102.

\section{References}

1. Klahr, S., and G. A. O. Alleyne. 1973. Effect of chronic proteincalorie malnutrition on the kidney. Kidney Int. 3:129-141.

2. Ichikawa, I., M. L. Purkerson, S. Klahr, J. L. Troy, M. Martínez-Maldonado, and B. M. Brenner. 1980. Mechanism of reduced glomerular filtration rate in chronic malnutrition. J. Clin. Invest. 65:982-988.

3. Blantz, R. C., K. S. Konnen, and B. J. Tucker. 1976. Angiotensin II effects upon the glomerular microcirculation and ultrafiltration coefficient of the rat. J. Clin. Invest. 57:419-434.

4. Myers, B. D., W. M. Deen, and B. M. Brenner. 1975. Effects of norepinephrine and angiotensin II on the determinants of glomerular ultrafiltration and proximal tubule fluid reabsorption in the rat. Circ. Res. 37:101-110.

5. DeRouffignac, C., J. P. Bonvalent, and J. Menard. 1974. Renin 
content in superficial and deep glomeruli of normal and salt-loaded rats. Am. J. Physiol. 226:150-154.

6. Lowry, O. H., N. J. Rosebrough, A. L. Farr, and R. J. Randall. 1951. Protein measurements with the folin phenol reagent. J. Biol. Chem. 193:265-275.

7. Natelson, S., and E. A. Natelson. 1975. Principles of Applied Clinical Chemistry. Vol. I. Plenum Publishing Corp., New York. 163-168.

8. Ogihara, T. 1977. A non-chromatographic, non-extraction radioimmunoassay for serum aldosterone. J. Clin. Endocrinol. \& Metab. 45:726-730.

9. Fejes-Tóth, G., J. Filep, and V. Mann. 1983. Effect of vasopressin on prostaglandin excretion in conscious dogs. J. Physiol. 344:389397.

10. Pullman, T. N., A. S. Alving, R. J. Dern, and M. Landowne. 1954. The influence of dietary protein intake on specific renal functions in normal man. J. Lab. Clin. Med. 44:320-332.

11. Baylis, C., W. M. Deen, B. D. Myers, and B. M. Brenner. 1976. Effect of some vasodilator drugs on transcapillary fluid exchange in the renal cortex. Am. J. Physiol. 230:1148-1158.
12. Zatz, R., T. W. Meyer, H. G. Rennke, and B. M. Brenner. 1986. Prevention of diabetic glomerulopathy by pharmacological amelioration of glomerular capillary hypertension. J. Clin. Invest. 77:19251930.

13. Anderson, S., T. W. Meyer, H. G. Rennke, and B. M. Brenner. 1985. Control of glomerular hypertension limits glomerular injury in rats with reduced renal mass. J. Clin. Invest. 76:612-619.

14. Steiner, R. W., and R. C. Blantz. 1978. Nonuniform antagonism by saralasin of multiple intrarenal effects of angiotensin II. Kidney Int. 14:703A.

15. Ichikawa, I., J. M. Pfeffer, M. A. Pfeffer, T. H. Hostetter, and B. M. Brenner. 1984. Role of angiotensin II in the altered renal function of congestive heart failure. Circ. Res. 55:669-675.

16. Frolich, J. C., T. W. Wilson, B. J. Sweetman, M. Smigel, A. S. Nies, K. Carr, J. T. Watson, and J. A. Oates. 1975. Urinary prostaglandins: identification and origin. J. Clin. Invest. 55:763-770.

17. Yue, T. L., D. R. Varma, and W. S. Powell. 1983. Effects of protein deficiency on the metabolism of arachidonic acid by rat pleural polymorphonuclear leukocytes. Biochem. Biophys. Acta. 751:332339. 